\title{
Folate and genomic stability: differential effect of methylated and oxidised folate on DNA damage and ROS production in human colon fibroblasts
}

\author{
E. Lendoiro ${ }^{1,2}$, W. Russell ${ }^{3}$, C. Bestwick ${ }^{3}$, G. Bermano ${ }^{1}$ and S.J. Duthie ${ }^{1}$ \\ ${ }^{1}$ School of Pharmacy and Life Sciences, Robert Gordon University, AB10 7GJ, ${ }^{2}$ Institute of Forensic Sciences, Faculty \\ of Medicine, University of Santiago de Compostela, Spain and ${ }^{3}$ Rowett Institute of Nutrition and Health, University of \\ Aberdeen, AB25 2ZD.
}

Folates are water-soluble B vitamins, which maintain DNA stability by regulating DNA biosynthesis, repair and methylation ${ }^{(1)}$. Low dietary folate status is associated with an increased risk of colon cancer ${ }^{(2)}$. Conversely, recent mandatory food fortification with oxidised folic acid has been linked with an increase in colon cancer incidence ${ }^{(3)}$. Moreover, high dose folic acid supplementation has been associated with an increase in premalignant adenomas or colon malignancies in some human intervention studies ${ }^{(4)}$. This study evaluates the ability of dietary folate and folic acid to maintain normal cellular characteristics, growth and viability, DNA stability, and endogenous reactive oxygen species (ROS) production in an in vitro human colon fibroblast cell model.

Primary human colon fibroblasts $(\mathrm{CCD}-18 \mathrm{Co})$ were cultured for up to 14 days, in either 5-methyl-tetrahydrofolate $\left(\mathrm{CH}{ }_{3} \mathrm{THF}\right)$ or folic acid at 3 plasma physiological concentrations corresponding to (1) post-supplementation (100 ng/mL), (2) nutritional sufficiency $(10 \mathrm{ng} / \mathrm{mL})$ or $(3)$ moderate deficiency $(2.5 \mathrm{ng} / \mathrm{mL})$. CCD-18Co cells were seeded in 12 -well plates at $1.6 \times 10^{4}$ cells per well and the effect of folate form and status measured on cell proliferation (cell growth using a Haemocytometer), cell viability and size (Cellometer ${ }^{\circledR}$ Cell Counter), and endogenous DNA strand breakage [Single Cell Gel Electrophoresis (SCGE)]. For ROS production, cells were seed in $25 \mathrm{~cm}^{2}$ flasks at $1 \times 10^{5}$ cells per flask and analysed by Flow Cytometry.

CCD-18Co colon fibroblasts exposed to $\mathrm{CH}_{3}$ THF showed significantly higher growth than those cultured in folic acid at 10 and 2.5 $\mathrm{ng} / \mathrm{mL}(\mathrm{p}<0.001)$. While rate of cell growth was similar in all $\mathrm{CH}_{3}$ THF concentrations (13.5-fold, 18.4-fold and 14.2-fold at 100, 10 and $2.5 \mathrm{ng} / \mathrm{mL}$, respectively), proliferation at lower folic acid concentrations (10 and $2.5 \mathrm{ng} / \mathrm{mL}$ ) was negligible (approx. 1.6-fold). Cell viability ranged from $69.2 \%-84.0 \%$ for $\mathrm{CH}_{3}$ THF and $35.7-46.8 \%$ for folic acid. $\mathrm{CH}_{3} \mathrm{THF}$ supported cell viability better than folic acid at all concentrations $(\mathrm{p}<0.02)$. A significant increase in cell diameter was observed in cells grown in folic acid compared with those grown in $\mathrm{CH}_{3}$ THF $[21.9 \mu \mathrm{m}(\mathrm{SEM}=1.2 \mu \mathrm{m})$ versus $17.8 \mu \mathrm{m}(\mathrm{SEM}=1.3 \mu \mathrm{m})]$ at $2.5 \mathrm{ng} / \mathrm{mL}(\mathrm{p}<0.03)$. Endogenous DNA strand breakage increased with decreasing folate status $(\mathrm{p}<0.03)$, with fibroblasts grown in folic acid showing approx. 0.8-fold higher DNA breakage than cells cultured in $\mathrm{CH}_{3}$ THF. ROS production was elevated in cells cultured in folic acid compared with those grown in $\mathrm{CH}_{3}$ THF (up to 3.8-fold) $(\mathrm{p}<0.02)$.

These results show that, compared with colon fibroblast cells exposed to $\mathrm{CH}_{3} \mathrm{THF}$, folic acid at physiological concentrations, alters several biomarkers associated with colon carcinogenesis including inducing abnormal proliferation, DNA instability and increased ROS production.

This work was funded by TENOVUS SCOTLAND.

1. Duthie SJ (2011) J Inherit Metab Dis 34, 101-109.

2. Giovannucci E (2002) J Nutr 132, 2350S-2355S.

3. Mason JB, Dickstein A, Jacques PF, et al. (2007) Cancer Epidemiol Biomarkers Prev 16(7), 1325-1329.

4. Cole BF, Baron JA, Sandler RS, et al. (2007) JAMA 297, 2351-2359. 